\title{
Kars Devlet Hastanesi'ne Bașvuran Hastalarda HBsAg, Anti-HCV ve Anti-HIV Seroprevalansı
}

\author{
HBsAg, Anti-HCV and Anti-HIV Seroprevalence of the patients apply to \\ Kars Public Hospital
}

\author{
Yeliz ÇETINKOL \\ Ordu Üniversitesi Tıp Fakültesi, Tıbbi Mikrobiyoloji Anabilim Dalı, Ordu, Türkiye
}

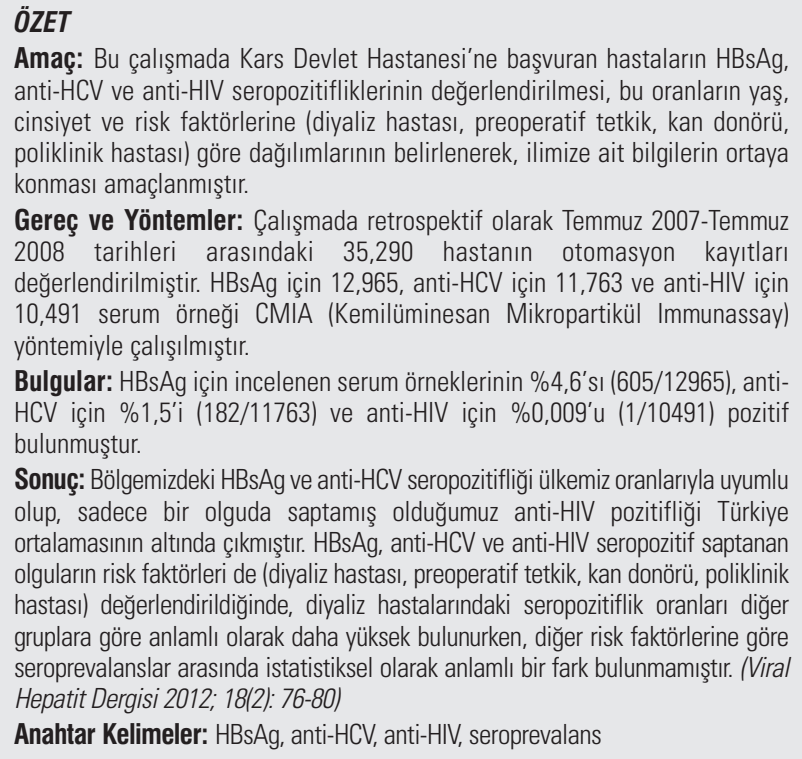

Gereç ve Yöntemler: Çalışmada retrospektif olarak Temmuz 2007-Temmuz 2008 tarihleri arasındaki 35,290 hastanın otomasyon kayıtları değerlendirilmiştir. HBsAg için 12,965, anti-HCV için 11,763 ve anti-HIV için 10,491 serum örneği CMIA (Kemilüminesan Mikropartikül Immunassay) yöntemiyle çalışılmıştır.

Bulgular: HBsAg için incelenen serum örneklerinin \%4,6'sı (605/12965), antiHCV için \%1, $5^{\prime i}$ (182/11763) ve anti-HIV için \%0,009'u (1/10491) pozitif bulunmuştur.

Sonuç: Bölgemizdeki HBsAg ve anti-HCV seropozitifliği ülkemiz oranlarılla uyumlu olup, sadece bir olguda saptamış olduğumuz anti-HIV pozitifliği Türkiye ortalamasının altında çıkmışır. HBsAg, anti-HCV ve anti-HIV seropozitif saptanan olguların risk faktörleri de (diyaliz hastası, preoperatif tetkik, kan donörü, poliklinik hastası) değerlendirildiğinde, diyaliz hastalarındaki seropozitiflik oranları diğer gruplara göre anlamlı olarak daha yüksek bulunurken, diğer risk faktörlerine göre seroprevalanslar arasında istatistiksel olarak anlamlı bir fark bulunmamıştı. (Viral Hepatit Dergisi 2012; 18(2): 76-80)

Anahtar Kelimeler: HBsAg, anti-HCV, anti-HIV, seroprevalans

\section{ABSTRACT}

Objective: In this study, it was aimed to present the information about seroprevalance rates of our city by determining the distributions of $\mathrm{HBsAg}$, antiHBs, anti-HCV, anti-HIV seropositivies according to gender, age and risk factors (dialysis patients, the preoperative tests, blood donors, outpatients) in the patients who admitted to the Kars State Hospital between July 2007 and July 2008. Materials and Methods: The electronic records of 29.227 patients were retrospectively evaluated. All tests were performed using chemiluminescent microparticle immunoassay method. In total, 12965 patients were tested for HBs Ag, 11763 for anti-HCV and 10491 for anti-HIV tests.

Results: The seropositivity rates for $\mathrm{HBsAg}$, anti-HCV, anti-HIV were $4.6 \%, 1.5 \%$, and $0.009 \%$, respectively.

Conclusion: The seropositivity rates for $\mathrm{HBsAg}$ and anti-HCV in our region were comparable to those seen across Turkey. Whereas, the seropositivity rates for antiHIV were lower than the average rate in Turkey. When the risk factors for $\mathrm{HBs} A g$ and anti-HCV seropositive patients (dialysis patients, the preoperative examination, blood donors, outpatients) were taken into consideration, the rates of seropositivity in dialysis patients were found to be significantly higher than the other groups. No statistically significant difference was found in the rates of seropositivity in the groups with other risk factor. (Viral Hepatitis Journal 2012; 18(2): 76-80)

Key words: HBsAg, anti-HBs, anti-HCV, anti-HIV, seroprevalence

\section{Giriş}

Yüksek morbidite ve mortaliteye yol açan hepatit B virus (HBV), hepatit C virus (HCV) ve insan bağışıklık yetmezlik virusu (Human ımmunodeficiency virus, HIV) enfeksiyonları dünyada ve ülkemizde halen önemli sağlık sorunları arasında yer almaktadır. Dünya çapında yaklaşık 300 milyon kişinin HBV, 200 milyon kişinin de HCV ile enfekte olduğu bilinmekte ve

Yazışma Adresi/Address for Correspondence: Dr. Yeliz Çetinkol, Ordu Üniversitesi Tıp Fakültesi, Tıbbi Mikrobiyoloji Anabilim Dalı, Ordu, Türkiye Tel.:_90 4522250185 E-mail: dryelizcetinkol@gmail.com Received/Geliștarihi: 03.07.2012 Accepted/Kabul tarihi: 27.08 .2012 
ülkemizde de bu hepatit virusları yaygın olarak görülmektedir. HBsAg taşıyıcılık oranının bölgeler arası farklılıklar göstermekle birlikte \%2-7 civarında olduğu ülkemiz, dünyada orta endemik bölge sınıfında yer almaktadır. Yüksek kronikleşme oranı ile son yıllarda dikati çeken ve önem kazanan HCV sıklığı ise ülkemizde \%1-2,4 arasında değişmektedir (1-3). Yarısından fazlası Afrika'da bulunan yaklaşık 40 milyon kişi HIV ile enfekte olup, yetişkinlerdeki prevalans \%1,1'dir. Ülkemizde Sağlık Bakanlığı 2003 verilerine göre; 1985 yılından günümüze toplam 3,671 HIV pozitif olgu bildirilmiştir (4).

HBV ve HCV enfeksiyonları kronik karaciğer hastalığı, siroz ve hepatosellüler karsinoma gelişme riski açısından büyük önem taşımaktadır (5). HBV'nin temel bulaşma yolları perkütan, perinatal, horizontal ve cinsel temastır. HCV'nin de bulaşı HBV'ye benzemekle birlikte parenteral yol daha ön planda yer almaktadır. HBV'nin, HIV'e göre 100 kat, HCV'ye göre de 10 kat daha enfeksiyöz olduğu bilinmektedir (6). Hepatit enfeksiyonlarının bulaş yollarının bilinmesi ve korunma yöntemlerinin uygulanması ile enfeksiyonun kontrol altına alınabilmesi mümkündür (7). Antiretroviral ilaçlardaki tüm gelişmelere ve yoğun aşı çalışmalarına rağmen HIV enfeksiyonu ise halen kontrol altına alınamamıştır. Diğer enfeksiyon hastalıklarının kontrolünde olduğu gibi HIV'in kontrol altına alınmasında da en önemli yöntem primer korunmadır. Hepatit B için yapılan ciddi aşılama çalışmaları sonucunda önümüzdeki yıllarda HBV enfeksiyonunda azalma; buna karşın HCV ve HIV infeksiyonlarında artış olacağı düşünülmektedir. Türkiye'de bir yılda yaklaşık 200,000 kişinin akut viral hepatite yakalandığı ve 4 milyon civarında da hepatit virüs taşıyıcısı olduğu tahmin edilmektedir (8).

\section{Gereç ve Yöntemler}

Bu çalışmanın amacı, bir yıllık sürede hastanemiz mikrobiyoloji laboratuvarına başvuran bireylerin serum örneklerindeki HBsAg, anti-HCV ve anti-HIV seropozitifliğinin değerlendirilerek, ilimize ait bilgilerin ortaya konması ve bu bilgilerin ülkemiz epidemiyolojik verilerine katkı sağlamasıdır.

Bu çalışma Temmuz 2007-Temmuz 2008 tarihleri arasında Kars Devlet Hastanesi Mikrobiyoloji laboratuvarı HBsAg, anti-HCV ve anti-HIV test sonuçlarının ve bazı demografik verilerin retrospektif olarak incelenmesiyle yapılmıştır. Kan örnekleri değişik şikâyetlerle polikliniklere başvuran, farklı tanılarla servislerde yatan ve diyaliz hastalarından alınmıştır. Ayrıca kan donörleri de çalışmaya dâhil edilmiştir. Kanlar santrifüj edilerek serumları ayrımış, lipemik ve hemolizli serumlar çalışmaya dahil edilmemiştir. Serum örnekleri bekletilmeden aynı gün CMIA (Kemilüminesan Mikropartikül Immunassay) yöntemiyle (Architect, Abbott, USA) üretici firmanın önerdiği prosedüre göre HBsAg, anti-HCV ve anti-HIV parametreleri çalışılmıştır. Anti-HCV ve anti-HIV pozitif çıkan testler ikinci kez aynı sistemle tekrarlanmıştır. Tekrarlanan testlerde anti-HIV pozitif bulunan serumlar doğrulama amacıyla, Refik Saydam Hıfzısıhha Merkezi Başkanlığı'na gönderilmiş, burada Western Blot ile doğrulaması yapılmıştır. Istatistiksel değerlendirme aşamasında "Ki-kare testi" kullanılmış ve anlamlılık sınırı olarak $p<0,05$ değeri kabul edilmiştir.

\section{Bulgular}

Bir yıllık süre içerisinde çeşitli poliklinik ve servislerdeki hastalardan ayrıca donör olarak başvuran hastalardan HBsAg

Tablo 1. HBsAg, anti-HCV ve anti-HIV seropozitifliğinin değerlendirilmesi

\begin{tabular}{lcccc}
\hline & Toplam sayı (K/E) & Seropozitif örnek sayısı (K/E) & Pozitiflik yüzdesi \% & Yaş ortalaması (yıl) \\
\hline HBsAg & $12965(4210 / 8755)$ & $605(198 / 407)$ & 4,6 & 42 \\
Anti-HCV & $11763(4295 / 7468)$ & $182(89 / 93)$ & 1,5 & 50 \\
Anti-HIV & $10491(3841 / 6650)$ & $1(0 / 1)$ & 0,009 & 42 \\
\hline
\end{tabular}

Tablo 2. Farklı risk gruplarında HBsAg, anti-HCV, anti-HIV seropozitifliğinin değerlendirilmesi

\begin{tabular}{|c|c|c|c|c|c|}
\hline & Diyaliz hastası & Preoperatif tetkik & Kan donörü & Poliklinik hastası & Toplam \\
\hline HBsAg & $4(\% 9,3)$ & $45(\% 4,9)$ & $132(\% 2,5)$ & $424(\% 6,3)$ & 605 \\
\hline seropozitif & (n: 43) & (n: 916) & (n: 5287) & (n: 6719) & (n: 12965) \\
\hline Anti-HCV & $3(\% 6,9)$ & $12(\% 1,3)$ & $82(\% 1,5)$ & $85(\% 1,5)$ & 182 \\
\hline seropozitif & (n: 43) & (n: 916) & (n: 5287) & (n: 5517) & (n: 11763) \\
\hline Anti-HIV & $0(\% 0,0)$ & $0(\% 0,0)$ & $0(\% 0,0)$ & $1(\% 0,009)$ & 1 \\
\hline seropozitif & (n: 43) & (n: 916) & (n: 5287) & (n: 4245) & (n: 10491) \\
\hline
\end{tabular}


için 12,965, anti-HCV için 11,763 ve anti-HIV için 10,491 kan örneği çalışılmıştır. HBsAg için incelenen 12,965 serum örneğinin \% 4,6'sı (605/12965), anti-HCV için incelenen 11,763 serum örneğinin \%1,5'i (182/11763) ve anti-HIV için incelenen 10,491 serum örneğinin \%0,009'i (1/10491) pozitif bulunmuştur.

HBsAg çalışılan serumların 198'i (\%32,7) kadın, 407'si $(\% 67,2)$ erkektir. Seropozitiflerin yaş ortalaması ise 42 yıl olarak bulunmuştur. \%1,5 seropozitiflik saptanan anti-HCV çalışılan serumların 89'u $(\% 48,9)$ kadın, 93'ü $(\% 51,1)$ erkek olup, seropozitiflerin yaş ortalaması ise 50 yıldır. Anti-HIV taraması yapılan serumların sadece 1 'inde seropozitiflik saptanmıştır ve bu kişi de 42 yaşında erkektir (Tablo 1). Pozitif sonuçların alındığı serolojik göstergelerde, cinsiyetlere göre seroprevalanslar arasında istatistiksel olarak anlamlı bir fark bulunmamıştır $(p>0,05)$.

HBsAg, anti-HCV ve anti-HIV seropozitif saptanan olguların risk faktörleri de (diyaliz hastası, preoperatif tetkik, kan donörü, poliklinik hastası) değerlendirilmiştir (Tablo 2). Diyaliz hastalarındaki HBsAg ve anti-HCV seropozitiflik oranları diğer gruplara göre anlamlı olarak daha yüksek bulunurken ( $p<0.05)$, diğer risk faktörlerine göre seroprevalanslar arasında istatistiksel olarak bir fark bulunmamıştır $(p>0,05)$.

\section{Tartıșma}

Viral hepatitler yüzyıllardır bilinmesine rağmen yüksek morbidite ve mortaliteye yol açması ve büyük ekonomik kayıplara neden olmasından dolayı, gerek dünyada gerekse ülkemizde önemli halk sağlığı sorunlarındandır. Yaşam standartlarının yükselmesi, aşılama programlarının yaygınlaşması, toplumsal bilincin artması ve yeterli farkındalığın oluşmasına rağmen HBV, HCV ve HIV enfeksiyonları günümüzde halen önemini korumaktadır (9-11). Sarılık olgularının çoğu viral hepatit kökenli olmasına karşın, anikterik olguların görünmeyen ve asıl toplum açısından tehlike oluşturan kısmı olduğu epidemiyolojik çalışmalarda belirtilmiştir (12). Akut viral hepatitlerin yarısına yakını B tipi hepatitlerdir. Hepatit B'nin önemi \%5 civarında kronikleşme göstermesi ve bunların önemli bir bölümünün de karaciğer sirozu ve hepatoselüler karsinomaya dönüşmesinden kaynaklanmaktadır (13). Hepatit C çok daha yüksek oranda kronikleşme eğilimindedir. Epidemiyolojik çalışmalar kronik hepatit C enfeksiyonu ile hepatoselüler karsinoma arasında güçlü bir ilişkinin olduğunu ortaya koymaktadır (14). Ülkemizde HBV ve HCV prevalansını araştıran çok sayıda araştırma yayınlanmıştır. Bu araştırmaların çoğu kan donörlerinde yapılan incelemeleri kapsamaktadır. Ülkemizde HBsAg pozitiflik oranının araştırıldığı otuz değişik çalışmada Doğu ve Güneydoğu Anadolu'da oranların daha da yüksek olduğu ve bu bölgelerde enfekte olma yaşının çocukluk çağına indiği anlaşılmaktadır $(15,16)$. Öner ve ark.'nın Mersin'de kan donörlerinde HBsAg, anti-HCV, anti-HIV ve VDRL seroprevelanslarını ve etkileyen faktörleri belirlemek amacıyla yaptıkları çalışmada, donörlerin \%2,2'inde HBsAg, \%0,4'ünde anti-HCV ve \% 0,2 anti-HIV pozitif olarak saptamışlardır. Sonuçta donörlerin \%2,8'inde en az bir kanla bulaşan enfeksiyon seropozitifliği ve seroprevelansın erkeklerde yaşla beraber arttığı tespit edilmiştir (17). Konya'da donörlerde HBV ve HCV enfeksiyonlarının sıklığını araştırmak amacıyla yapılan başka bir çalışmada, 2003-2009 tarihleri arasındaki kan donörleri incelenerek HBsAg seropozitifliği \%1,53'ünde, anti-HCV \%0,5'inde saptanmıştır. Yıllar içinde HBV seropozitifliğinde bir azalma tespit edilirken, anti-HCV seropozitifliğinin ülkemizdeki diğer çalışma sonuçlarıyla benzer olduğu görülmüştür (18). Yapılan benzeri birçok çalışmada, HBsAg pozitifliğinde önceki yıllara göre düşüş saptandığı gözlenmiştir. Bu durumun sebebi olarak halk sağlığı ile ilgili alınan önlemler doğrultusunda hepatit B aşılama uygulamasının yaygınlaşması ve halkın konuyla ilgili bilgilendirilmesi gösterilebilir. Ayrıca kan merkezlerinde uygulanan eğitici programlar, donör sorgulama formunun etkin bir şekilde doldurulması ve asker donörler yerine gönüllü sivil donör uygulamasına geçilmesinin de bu düşüşte önemli rol oynadığı düşünülmektedir (18-22).

Viral hepatitlere neden olan etkenlerin sıklığı değişik bölgeler, yaşlar ve sosyoekonomik yaşam koşullarında farklılıklar göstermektedir. Ülkemizde yapılan çalışmalarda HBsAg pozitifliğinin değişik toplum kesimlerinden gelen gruplar arasında farklı olduğu görülmektedir. Aydın'da yapılan bir çalışmada sağlıklı donörlerde HBsAg \% 1,9, Adana'da yapılan bir çalışmada gönüllü kan donörlerinde $\% 1,5$, askerlerde ise $\% 4,3$ oranında pozitif bulunmuştur $(23,24)$. Türkiye genelinde $\% 3,9$ 12,5 arasında HBsAg pozitiflik oranlarına rastlandığı kabul edilmektedir. Toy ve ark.'nın yaptığı geniş çaplı bir çalışmada, hepatit B'nin mevcut durumunu ortaya koymak için, Türkiye'deki kronik hepatit B'nin yaş ve bölgeye özgü prevalanslarını incelemişlerdir. Ülkemizde 1999 ve 2009 yılları arasında yapılan 339 çalışma gözden geçirilerek, kronik hepatit B vakalarının toplam sayısının yaklaşık 3,3 milyon ve toplam nüfusta prevalansın \%4,57 olduğu ortaya konmuştur. Çalışmanın sonucunda Türkiye'de kronik hepatit B prevalansında yaş grupları ve bölgeler arası büyük farklılıklar bulunduğu ve bu hastalığın hala ciddi bir sağlık sorunu olmaya devam ettiği gösterilmiştir (25). Batı illerinden daha düşük oranda HBsAg pozitifliği bildirilirken; Diyarbakır, Elâzığ, Van gibi Doğu ve Güneydoğu Anadolu illerinden genellikle \%8'in üzerinde değerler bildirilmektedir (26). Dursun ve ark. Diyarbakır, Batman, Mardin ve Şanlıurfa illerinde HBsAg pozitifliğini \%7 oranında bildirirken, Bolu'da \%2,85 ve Isparta'da \%3,5 gibi farklı oranlar olarak bildirilmiştir (27-29). Kars ili için \%4,6 olarak saptamış olduğumuz HBsAg seropozitiflik oranı, Doğu ve Güneydoğu bölgelerinden bildirilen oranlardan daha düşüktür. 
Türkiye'de HCV prevalansı açısında bölgeler arasında önemli farklılık yoktur ve sıklık \%0,3-1,8 arasında değişir. Dünya genelinde bu oran ise \%3'tür (30). HCV seropozitifliğini belirlemek amacıyla yapılan değişik çalışmalarda anti-HCV pozitifliği; Isparta bölgesinde \%0,52 bulunurken, Sivas ve Mersin bölgelerinde yapılan farklı çalışmalarda \%0,4 bulunurken (15), Erden ve ark.'nın Istanbul bölgesinde kan donörlerinden yaptığı bir diğer çalışmada da \%2,1 olarak saptanmıştır (31-34). Hepatit B'ye göre daha düşük prevalansı olan HCV'nun kronik hepatitlerdeki önemi artmaktadır. Ülkemizde kronik hepatit C oranı 2000-2006 yılları arasında farklı merkezlerden toplam 1,076,495 kan donöründe \%0,54 olarak saptanmıştır (1). Bizim çalışmamızda anti-HCV pozitifliği \% 1,5 olarak saptanmış olup, bu değer Türkiye ortalaması ile uyumludur.

Anti-HIV seroprevalansı saptamak amacıyla yapılan farklı çalışmalarda HIV seropozitifliği saptanmayan pek çok sonucun yanında, \%4,7 ile \%0,01 arasında değişen oranlarda anti-HIV seropozitifliği bildirilen çalışmalar da vardır (32,35-39). Anti-HIV için incelediğimiz 10,491 serum örneğinden sadece bir tanesinde Refik Saydam Hıfzısıhha Merkezi Başkanlığı'nca da doğrulanan pozitif sonuç bulunmuştur. Bu oranın Türkiye ortalamasının çok altında kalmış olması ilimiz için sevindirici bir durumdur. Bununla birlikte son durumun yeniden gözden geçirilmesi gerekmektedir.

Hepatit ve HIV enfeksiyonları sırasında oluşan komplikasyonlar, kronikleşen vakaların hayat boyu izlem gerektirmesi ve tedavi gerektiren vakaların mali boyutu düşünüldüğünde; enfekte olan kişilerin saptanması koruma, kontrol ve tedavi programlarına katkı sağlayacaktır. Toplum sağlığı açısından ilimizdeki ve ülke genelindeki sayıların oldukça yüksek olduğu, yeni epidemiyolojik çalışmalarla seroprevalansların belirlenerek toplumu bilgilendirmenin ve gerekli önlemlerin alınmasının temel hedef olması gerektiğini düşünmekteyiz.

\section{Kaynaklar}

1. Mıstık R. Türkiye'de viral hepatit epidemiyolojisi yayınların irdelenmesi. Tabak F, Balık I (eds.), Viral Hepatit 2007. 1. Baskı, Istanbul: Viral Hepatitle Savaşım Derneği; 2007; s.10-50.

2. Quer J, Esteban J. Epidemiology. In: Thomas HC, Lemon S, Zuckerman AJ (eds.), Viral hepatitis. Third Edition. Massachusetts, USA: Blackwell Publishing; 2005; s.407-425.

3. Sünbül M. HCV enfeksiyonlarının epidemiyolojisi ve korunma. Tabak F, Balık I (eds.), Viral Hepatit 2009. 1. Baskı. Istanbul: Viral Hepatitle Savaşım Derneği; 2009; s.208-219.

4. Erensoy S. HIV ve AIDS. Ustaçelebi Ş, Abacıoğlu H, Badur S (eds.), Moleküler, klinik ve tanısal viroloji. 1.Baskı. Ankara: Güneş Kitabevi; 2004; 223-243.

5. Ustaçelebi Ş, Ergünay K. Hepatit C virusu. Ustaçelebi Ş, Abacıoğlu H, Badur S (eds.), Moleküler, klinik ve tanısal viroloji. 1.Baskı. Ankara: Güneș Kitabevi; 2004; 203-209.

6. Weinbaum C, Lyerla R, Margolis HS. Centers for Disease Control and Prevention. Prevention and control of infections with hepatitis viruses in correctional settings. Centers for Disease Control and Prevention. MMWR Recomm Rep. 2003; 52(RR-1): 1-36.
7. Çetin M, Temiz M, Aslan A, Turhan E. Mustafa Kemal Üniversitesi Tıp Fakültesi Hastanesi araştırma görevlilerinin hepatit B virusu infeksiyonuna ilişkin bilgi düzeylerinin de-ğerlendirilmesi. Viral Hepatit Derg. 2007; 12: 121-7.

8. Badur S: Ülkemizde viral hepatitlerin durumu. Viral hepatit ' 94. Kilıçturgay K (eds.), Viral hepatit' 94. 1. Baskı. İstanbul: Nobel Tıp Kitapevi; 1994; s.15.

9. Akçam Z, Akçam M, Coşkun M, Sünbül M. Hastane personelinin viral hepatitler ve hepatit $B$ aşısı ile ilgili bilgi düzeyinin değerlendirilmesi. Viral Hepatit Derg. 2003; 8: 32-5.

10. Polat M, Öğüt S, Orhan H, Sucaklı MB. Isparta ve Burdur'da çalışan hemşirelerin hepatit B virüs enfeksiyonu konusundaki bilgi, tutum ve davranışları. Viral Hepatit Derg. 2006; 11: 89-94.

11. Robinson WS. Hepadnaviridae: Hepatitis B virus and hepatitis D virus. Mandell, Douglas and Bennett's principles and practice of Infectious disease. Mandell GL, Bennett JE, Dolin R (eds.), 5 th ed. Churchill Livingstone; 2000; s.1652-1678.

12. Afşar I, Güngör $S$, Özbaş $G$ ve ark. Atatürk Eğitim ve Araştırma Hastanesi Mikrobiyoloji laboratuvarı HBsAg, anti-HCV ve antiHIV seropozitifliğinin 2003 yılı değerlendirmesi. Izmir Atatürk Eğitim Hastanesi Tıp Derg. 2005; 43(1): 9-12.

13. Moradpour D, Wends JR. Understanding Hepatitis B virus infection. N Eng J Med. 1995; 332: 1092.

14. Ökten EA. HCV infeksiyonu, giriş. Kılıçturgay K (eds.), Viral Hepatit' 98. 1. baskı, Istanbul: Nobel Tip Kitapevleri; 1998; s.138.

15. Füsun ZA. Hepatit B virüsü enfeksiyonu. Sted Derg. 2003; 12(6): 211-4.

16. Tunç $N$, Eraydın H, Çetinkaya E, Oduncu MK, Toy Ş. Siirt Devlet Hastanesi'ne Başvuran Hastalarda HBsAg, Anti-HBs, Anti- HCV ve Anti-HIV Seroprevalansı. Viral Hepatit Derg. 2011; 17(1): 7-11.

17. Öner S, Yapıcı G, Şaşmaz CT, Kurt AO, Buğdaycı R. Hepatitis B, hepatitis C, HIV, and VDRL seroprevalence of blood donors in Mersin, Turkey. Turk J Med Sci. 2011; 41 (2): 335-41.

18. Turan H, Şerefhanoğlu K, Kanat-Ünler G, Arslan H. Konya Ilinde Kan Donörlerinde HBsAg ve Anti-HCV Seroprevalansı ve Yaş ve Cinsiyetle Illişkisi. Klimik Dergisi. 2011; 24: 36-9.

19. Güzelant A, Kurtoğlu MG, Kaya M, Keşli R, Baysal B. Kan vericilerinde ve bir ağız-diş sağlığı merkezi çalışanlarında hepatit $B$, hepatit $C$ ve HIV seroprevalansı ile vericilerde risk faktörlerinin araştırılması. Infeks Derg. 2008; 22: 189-95.

20. Kocak N, Hepgul S, Ozbayburtlu S, Altunay H, Ozsoy MF, Kosan E, et al. Trends in major transfusion-transmissible infections among blood donors over 17 years in Istanbul, Turkey. J Int Med Res. 2004; 32: $671-5$.

21. Kaya S. Kan donörlerinde hepatitis B virusu, hepatit $C$ virusu ve insan immun yetmezlik virusu infeksiyonu ve sifilis sıklığı. Klimik Derg. 2008; 21: 65-8.

22. Ağuş N, Özkalay Yılmaz N, Cengiz A, Şanal E, Sert H. Kan donörlerinde HBsAg, anti-HCV, anti-HIV seroprevalansı. Ankem Derg. 2008; 22: 7-9.

23. Sakarya S, Tuncer G, Yaşa G, Çiçek C, Kadıköylü G, Yükselen V. Aydın bölgesindeki kan donörlerinde HBsAg, ve anti-HCV prevalansı ve yaş ve cinsiyetle ilişkisi. Klimik Derg 2001; 14: 22-4.

24. Hazar S, llkit $M$, Akan E, Girmen A. Gönüllü ve asker kan vericilerinde $\mathrm{HBsAg}$, anti $\mathrm{HCV}$ ve anti-HIV $1 / 2$ antikorlarının araştıııması. Infeksiyon Derg 1998; 12: 19-22.

25. Toy M, Önder FO, Wörmann T, Bozdayi AM, Schalm SW, Borsboom GJ, et al. Age- and region-specific hepatitis B prevalence in Turkey estimated using generalized linear mixed models: a systematic review. BMC Infec Dis. 2011; 11:337.

26. Bilgiç A, Özacar T. Hepatit B Virusu. Willke Topçu A, Söyletir G, Doğanay M (eds). Infeksiyon hastalıkları ve mikrobiyolojisi. 2.Baskı. Istanbul: Nobel Tip Kitapevleri; 2002: s.1350-1370.

27. Mehmet D, Meliksah E, Serif Y, Gunay S, Tuncer O, Zeynep S, et al. Prevalence of hepatitis $B$ infection in the southeastern region of Turkey: comparison of risk factors for HBV infection in rural and urban areas. Jpn J Infect Dis. 2005; 58: 15-9. 
28. Karabay O, Serin E, Tamer A, Gökdoğan F, Alpteker H, Ozcan A, et al. Hepatitis B carriage and Brucella seroprevalence in urban and rural areas of Bolu province of Turkey: a prospective epidemiologic study. Turk J Gastroenterol. 2004; 15:11-3.

29. Demirci $M$, Arıdoğan BC, Taşkın P, Arda M. Isparta'da değişik yaş gruplarında hepatit B belirleyicilerinin seroprevalansı. Viral Hepatit Derg 2000; 6: 59-62.

30. Abacıoğlu H. Hepatit C virusu. Ustaçelebi Ş (eds.), Temel ve Klinik Mikrobiyoloji. 1.Baskı. Ankara: Güneş Kitapevi; 1999: s.881-888.

31. Kaya S, Arıdoğan BC, Adiloğlu AK, Demirci M. Isparta Bölgesi Kan Donörlerinde HBsAg ve anti- HCV seroprevalansı. SDÜ Tıp Fak Derg. 2005: 12: 36-8.

32. Özdemir L, Alim A, Arslan S ve ark. Sivas ilinde berber ve kuaförlerde HBV, HCV ve HIV seroprevalansı. Cumhuriyet Üniv Tıp Fak Derg. 2004; 26: 153-6.

33. Erden $S$, Büyüköztürk $S$, Calangu $\mathrm{S}$. Poliklinik hastalarında $\mathrm{HBsAg}$ anti-HBs ve anti-HCV seroprevalansı. Türk Mikrobiyol Cem Derg. 2000; 30: 131-4.
34. Ersöz G, Şahin E, Kandemir Ö ve ark. Mersin Üniversitesi Tıp Fakültesi Hastanesi sağlık personelinde HAV, HBV, HCV seroprevalansı ve hepatit B aşılaması. Viral Hepatit Derg. 2006; 11: 84-8.

35. Uyanık MH, Malçok HK, Aktaş O. Kan donörlerinde hepatit $B$, hepatit C ve HIV-1/2 seroprevalansı. Atatürk Üniv Tıp Derg. 2004; 36: 35-8.

36. Uzun C. Kan donörlerinde HBsAg, Anti-HCV, Anti-HIV ve RPR sonuçlarının değerlendirilmesi. Türk Mikrobiyol Cem Derg. 2008; 38: 143-6.

37. Tekay F. Hakkari ilinde HBV, HCV ve HIV seroprevalansı. Dicle TIp Derg. 2006; 33: 170-3.

38. Mırsal $H$, Kalyoncu $A$, Pektaş Ö ve ark. Damar yolundan eroin kullananlarda hepatit $B$, hepatit $C$ ve HIV yaygınlığı. Journal of Dependence. 2003; 4: 10-4.

39. Arabacı F, Şahin HA, Şahin I, Kartal Ş. Kan donörlerinde HBV, HCV, HIV ve VDRL seropozitifliği. Klimik Derg. 2003; 16: 18-20. 